Pro-social or Pro-management ? A critique of the conception of employee voice as a pro-social behaviour within Organisational Behaviour

Forthcoming British Journal Of Industrial Relations

Michael Barry

And

Adrian Wilkinson

Griffith University

Nathan

4111

QLD

Australia 


\section{Pro-social or Pro-management ? A critique of the conception of employee voice as a pro-social behaviour within Organisational Behaviour}

For many years, the ER literature took the perspective that employee voice via trade unions could channel discontent and reduce exit thereby improving productivity. In Organisational Behaviour (OB) research voice has also emerged as an important concept, and a focus of this research has been to understand the antecedents of the decision of employees to engage or not engage in voice. In OB research however, voice is not viewed as it is in ER as a mechanism to provide collective representation of employee interests. Rather, it is seen as an expression of the desire and choice of individual workers to communicate information and ideas to management for the benefit of the organisation. This paper offers a critique of the OB conception of voice, and in particular highlights the limitations of its view of voice as a prosocial behaviour. We argue that the OB conception of voice is at best partial, because its definition of voice as an activity that benefits the organisation leaves no room for considering voice as a means of challenging management, or indeed simply as being a vehicle for employee self-determination.

\section{Introduction}

Employee voice has been a major topic in the field of employment relations (ER) for many years. In the 1980s, the ideas of Hirschman (1970) inspired interest in voice as an alternative to employee exit, and the early work on voice focused on unions as the main instrument of voice (Freeman and Medoff 1984). The continuing difficulties facing organised labour have, more recently, given voice broader significance within the field and there has been interest in voice in non-union as well as union contexts (Benson 2000; Boxall et al. 2007; Gollan et al. 2014; Gomez et al. 2010). In contemporary ER studies, voice mechanisms are seen as viable substitutes for flagging unionism, or alternatively, as possible ways of substituting other mechanisms for unions in instances when employee voice schemes are initiated by management (Charlwood and Pollert 2014; Marchington 2007; Wilkinson et al 2013).

For many years, the ER literature adopted Freeman and Medoff's (1984) view that collective voice could channel discontent and reduce exit thereby improving productivity. Freeman and Medoff (1984) saw trade unions as the best agents to provide such voice, as they were generally independent of the employer and thus added legitimacy. However, it is important to note that voice structures can be contested. There can be tension between the aspirations of employees for voice, including an independent form of voice, and a desire by management to institute voice as part of its human resource management (HRM) agenda. 
Employee voice has also emerged as an important concept for Organisational Behaviour (OB) scholars who are interested in understanding the antecedents of the decision of employees to engage or not engage in voice (Greenberg and Edwards 2009; Morrison 2011, 2014). In OB research however, voice is not viewed as it is in ER as a mechanism to provide collective representation of employee interests. Rather, it is seen as an expression of the desire and choice of individual workers to communicate information and ideas to management for the benefit of the organisation. The OB literature follows the highly cited definition of voice that is offered by Van Dyne and Le Pine (1998), which is that it is discretionary, pro-social, largely informal, individual behaviour. For OB, "prosocial" is behaviour that is defined as being other-regarding (rather than self-regarding), and of benefit to the organisation or the work unit. Interestingly, OB research on voice has extended into mainstream management journals, giving this interpretation of voice greater reach, and also potentially challenging other conceptions of voice. In this paper, we have been stimulated by two recent review papers that were written with the intention of being broad integrative reviews of the entire voice field (Klaas et al. 2012; Morrison 2011). Of concern to us is that although these papers are published in management rather than OB journals, they do not engage with conceptions of voice outside of OB, such as those coming from ER. Consequently, they are not integrative reviews because they do not consider other conceptualisations, but instead ignore them or shunt them down another conceptual and theoretical path, leaving them sealed off as irrelevant to the view of voice which they seek to present.

This paper offers a critique of the OB conception of voice, and in particular highlights the limitations of its view of voice as a pro-social behaviour. At the outset, this paper acknowledges and will argue that the $\mathrm{OB}$ conception of voice is important in highlighting the value of constructive, individual employee voice behaviour, and in this way has much to offer an ER audience. Indeed, in focusing on the formal and collective mechanisms of voice, we would concede that ER has tended to discount the contribution of communicative and relational aspects of individual voice behaviour. However, we argue that the OB conception of voice is at best partial, because its definition of voice as an activity that benefits the organisation leaves no room for considering voice as a means of challenging management, or indeed simply as being a vehicle for employee self-determination.

We argue that the OB conception of voice is narrow because OB researchers view employee behaviour from a unitarist lens in which 'what is good for the firm must be good for the worker'. This view does not properly consider how the unequal employment relationship creates in one way a divergence of interests between workers and management that gives workers cause to have a voice on their own terms, and in another way creates a power imbalance that can limit the capacity of workers to engage in voice. Given its frame of reference, the OB conception of voice is divorced from the 
historical development of mechanisms of employee representation as vehicles for creating voice opportunity. Operating within this unitarist lens, OB voice does not properly consider why there is a need for a full range of voice mechanisms, including formal and informal as well as pro-social and critical/pluralist. Indeed, the dominant view of behaviour that does not meet the narrow test of being pro-social, is that it is complaining and, therefore, is not considered voice.

Our critique of $\mathrm{OB}$ voice goes beyond what we see as its narrow conception, to question what we see as a more fundamental limitation. OB regards employee voice as a discretionary, individual behaviour, and seeks to understand the antecedents of the choice to either raise or withhold voice. However we would contend, as we argue throughout the paper, that to ignore the ER conception of voice leaves $\mathrm{OB}$ open to failing its own research agenda. Our argument, fleshed out in detail throughout the paper, is summarised as follows. Firstly, in focussing on voice as a discretionary behaviour, OB does not properly consider the ways in which organisations create cultures of voice or silence that act as supply-side opportunities or constraints. In this way, discretionary, individual behaviour, as the ER perspective sees it, is institutionally embedded in ways that structure and limit the "choice" to voice. Coupled with this is an inadequate consideration in the OB literature of how the broader regulatory context, which is crucial to ER, shapes and constrains opportunities for employees to engage in voice behaviours. Secondly, in examining individual voice (and isolating collective voice behaviour such as that which ER focuses on), it can be very difficult to distinguish between the motives of different employees to voice in ways that might be either self-regarding or other-regarding. We would see self-regarding voice behaviour, or what is often referred to as employee impression management behaviour, as not meeting the OB test of pro-social behaviour because it is behaviour that is intended to benefit the individual rather than the work unit or organisation. Thirdly, and related to this point, we will demonstrate that the OB definition of pro-social behaviour is deficient by showing that the range of voice behaviour that employees engage can meet some aspects of this test but not others. For example, we will cite sociology of work literature on "soldiering" to highlight that individual voice can be seen as other-regarding behaviour, and also further the aims of the work unit itself, but nevertheless be consciously intended to frustrate or impede organisational goals. This behaviour, which we would argue is clearly "social”, would both meet and fail the test of pro-social behaviour according to OB.

We see the key features of ER voice as follows: voice is viewed as how employees are able to have a say in work activities and organisational decision-making issues (Freeman et al. 2007). A recent definition states that employee voice is: "the ways and means through which employees attempt to have a say and potentially influence organisational affairs about issues that affect their work and the interests of managers and owners" (Wilkinson et al. 2014: 5). This is a broad definition which 
encompasses a variety of voice mechanisms, regardless of the institutional channel through which voice operates (which includes speak-up programmes, quality circles, team work, collective negotiation or informal means). Voice encompasses the myriad of individual discretionary employee behaviours as set out in the OB literature, but also includes the various ways in which employees challenge managerial behaviour, either individually or through collective behaviours and mechanisms, and also includes self-determining efforts by employees to identify themselves in ways that are set aside from the interests of the firm. Although ER has a preoccupation with institutions which are vehicles for voice, Budd (2014) reminds us that voice is not just a constructive process, rather voice in its own right is a means of employee self-determination.

In the next section we briefly review the concept of employee voice within the ER literature. We will then examine how voice is conceptualised within the OB field. From there, we examine how the conception of voice as a pro-social behaviour is problematic from an ER perspective, and we explain the value of retaining an ER approach to understanding employee voice. We then extend our discussion to look at the related notion of silence, and again suggest limitations in the OB approach. In offering this critique of the $\mathrm{OB}$ conception of voice and silence, we seek to revive the term 'employee voice' from what has become the impoverished notion which currently exists in the OB voice literature. We argue that employee voice is too important to be left to a single discipline that so narrowly defines its reach, and therefore limits its broader practical and policy implications.

\section{Voice in ER and HRM}

In this section we examine the conceptual development of voice within the ER field, show how the ER and HRM views of voice have diverged over time, and highlight the relative strengths and weaknesses of the ER and HRM conceptions of voice. Most ER researchers go back to the classic study of Hirschman (1970) for conceptual grounding on voice. Hirschman (1970) developed a model of exit/voice/loyalty (EVL) which was subsequently interpreted and refined for an ER audience by Freeman and Medoff (1984), who used the exit/voice framework as an analytical tool to distinguish between non-union and union contexts. The definition that Hirschman (1970: 30) used for voice was "any attempt at all to change, rather than escape from an objectionable state of affairs", which is widely cited in ER research on voice.

While these are the two studies most often cited in ER research, Kaufman (2014a) points out there is a much longer, neglected history of ER research on voice, with the term employed for around 100 years. As Kaufman (2014a) notes, both Karl Marx and Adam Smith expressed interest in the ways and means in which labour expressed its voice. Kaufman (2014a) also argued that for much of the $20^{\text {th }}$ 
century, personnel management sat within the broad field of labour and employment relations. It was only in the 1980s that HRM displaced personnel administration and emerged as a distinct disciplinary field. HRM sought to provide a more strategic view of employment by showing how management efforts to garner employee commitment could advance the bottom line, and a key assumption that underlined this was that voice should be linked to firm performance. From a HRM perspective, setting up employee voice mechanisms potentially allows staff to influence events at work, but having a voice does not mean it is listened to. So while ER and HRM are often lumped together, especially in the UK where the scholars share a common intellectual tradition, there are clear differences of emphasis. ER scholars have tended to be more interested in indirect voice such as collective employee representation through trade unions, or more recently, non-union structures such as consultative committees or councils. HRM scholars have been more interested in direct voice schemes that allow for individual employee involvement such as task-based participation and upward problem solving (Marchington 2007; Mowbray et al. 2014). In the HRM strand, it is management who decide whether or not workers have a voice, and it is managers rather than employees, who decide which mechanisms to utilise so it can be voice without muscle (Kaufman and Taras 2010). This approach is quite different to the theoretical underpinnings of voice in ER where voice has been closely associated with employee representation and, therefore, tied to an important debate about the current and future prospects of trade unions. ER and HRM literatures attach different meaning and values to the term voice (Wilkinson and Fay 2011), with the HRM literature more closely aligned with the OB conception of voice, in that its utility is primarily defined in terms of the value of employee voice to the firm. We also note recent papers which suggest that the trajectory of HRM research is towards OB (Godard 2014; Harley 2014). For these reasons, for the remainder of this paper we will limit our discussion to ER voice and OB voice, and our argument will emphasise key differences in these two disciplinary perspectives and how their respective conceptions of voice diverge.

From an ER perspective voice is an expression of the desire of workers to have their own say over matters that affect their working lives (Dundon and Rollinson 2011). This broad approach to employee voice brings the concept closer to that of a political process in which voice is seen as an expression of industrial democracy. This argument is exemplified by Budd (2004; 23-28), who asserts that voice does not need to fulfil a constructive purpose; it is sufficient in itself for voice to be a means of employee self-determination. Budd's (2004) approach shows us that the mainstream ER view has, in its own way, pushed employee voice down a narrow path that seeks to identify voice with particular mechanisms or structures that operate as vehicles to air and redress employee grievances. Indeed, the 'Hirschmanian' framework takes a grievance as a starting point to voice, for in that case it was the dissatisfaction of a trading partner with a repeated transaction that might lower loyalty and lead to possible exit. 
Thus while we are criticising OB research for neglecting the important aspects of voice that they see as 'complaining', we also acknowledge that ER research, stemming from Hirschman, can also be criticised for focussing too heavily on the component of voice that is related to dissatisfaction. In applying the exit/voice framework to unions, Freeman and Medoff (1984) can be argued to have embedded this limitation of the ER conception within a predominantly collective framework. In other words, ER research has remained preoccupied with the collective mechanisms of voice that provide opportunity to air and redress grievances, just as OB research is preoccupied with the individual, communicative aspects of voice that they claim reveal employee pro-social behaviour.

In a recent study comparing employee voice in the United Kingdom and France, Marsden (2013: 251) highlighted this very limitation, claiming that his findings showed that individual voice is much more extensive than the ER field supposes and that: "the dichotomy between no voice and collective voice needs to be reviewed". Similarly, Budd (2014: 478) says that:

"the traditional industrial relations emphasis on collective voice through collective bargaining is excessively narrow. Richer understandings have and continue to come from including nonunion collective voice as well as various dimensions of individual voice within our conceptualization of employee voice. Similarly, the frequent approach of starting with Hirschman's (1970) definition of voice is excessively narrow because employee voice is then linked so strongly with complaining rather than broader conceptualizations of input, expression, autonomy, and self-determination".

Budd (2004: 24-28) offers a possible bridge between the ER and OB conceptions of voice by highlighting voice as a means of self-determination and thus being present without being attached to a specific dissatisfaction. By adding self-determination to industrial democracy, he argues that voice can be both individual and collective: "The industrial democracy dimension of voice suggests that a collective voice component is necessary while the self-determination dimension implies that individual voice mechanisms are also important” (Budd 2004: 28).

We would argue that ER needs a conception of voice that encompasses both individual and collective, as well as the relational and communicative aspects of voice on the one hand, and the formal and structural aspects on the other. However, we maintain that an important point of distinction remains between the ER and OB voice research, that is, the basis of the ER perspective is that it sees voice as being grounded in the asymmetrical employment relationship which provides a structure of management authority with some limits (Marsden 1999). Because employees seek voice to, in some 
ways, redress an inherent power imbalance, there is a clear sense that workers use voice to express interests that are separate from, and sometimes in conflict with those of management. While voice is seen as a legitimate expression of workers' interests, it is also understood that management may have its own agenda, and may seek to suppress voice where it is being raised to challenge managerial authority. While OB does talk about power in relation to antecedents related to voice (in particular studies on leadership) this is at the more individual level and relates to position power rather than reflecting more fundamental imbalances in the employment relationship. Equally OB does not tend to take note of different interests between workers and managers. For example, Detert and Burris (2007: 870) note that "to speak up, by definition, involves sharing one's ideas with someone with the perceived power to devote organizational attention or resources to the issue raised". Therefore, we contend that the $\mathrm{OB}$ view is faulty because it fails to acknowledge that there can be genuine differences of interest between workers and owners/managers and that the actors have different levels of power when asserting their interests.

\section{Voice in OB: its conception and limitations}

The concept of employee voice has become widely used outside of ER in management and OB studies. Not surprisingly, in these studies voice is viewed in terms of its potential to add value to the organisation. In OB research, voice is examined as a discretionary, individual employee behaviour. For instance, Morrison's (2011) overarching review of voice literature notes that while the specific wording may differ, the OB definitions share three key features. Firstly, voice is an act of verbal expression, where a message is conveyed from a sender to a recipient. Secondly, voice is defined as discretionary behaviour - individuals choose whether or not to engage in this behaviour at any particular moment in time, a choice that is affected by a variety of factors. Thirdly, voice should be constructive in its intent. The objective is to bring about improvement and positive change, not simply to complain (Morrison 2011: 375).

To understand how the OB field has become focused on a narrow interpretation of voice, it is instructive to look at how the OB voice literature has evolved. Until the early 1990s, the OB discipline had conceptualised and studied a range of constructs that were related to, or could be construed as voice, such as whistleblowing and principled organisational dissent, but Van Dyne et al.'s (1995) paper on extra-role behaviours in the organisational citizenship behaviour literature began to narrow the construct of voice. They identified voice as an extra-role challenging/promotive behaviour, where the employee: "proactively challenge[s] the status quo and make[s] constructive recommendations for change” (1995: 266). Later work by Van Dyne and LePine (1998) produced a new measure of voice behaviour. They recognised that their definition differed to previous definitions 
of voice which covered grievance procedures, participation in decision-making and due process. This created two separate streams of voice literature within the OB discipline, i.e. pro-social voice and justice-oriented voice (Mowbray et al. 2014).

We see some flirting with wider concepts of voice within OB, such as that proposed by Liang et al. (2012), who make the distinction between promotive and prohibitive voice, and Morrison herself (2011, 2014) labelling voice as suggestion-focused and problem-focused and including remedial voice alongside prohibitive and problem-focused voice to explain how the voice content can refer to information about serious problems. But even in in her more recent review, Morrison (2014: 179180) contends that the "underlying motivation for voice is prosocial in nature" (citing Grant and Ashford 2008; Van Dyne et al. 2003) "that is, voice is motivated by the desire to bring about a constructive change for the organisation or for one or more stakeholders". Indeed, Morrison (2014: 180 ) lists the following studies as support for the idea that voice is pro-socially motivated: Fuller et al. (2006), Liang et al. (2012), Liu et al. (2010), Tangirala and Ramanujam (2008a,b), Nikolaou et al. (2008), Lam and Meyer (2013), Tangirala et al. (2013), and Wang and Hsieh (2013).

Thus, while it is accurate to say that OB voice is not only pro-social, the study of pro-social voice is clearly the mainstream in the OB literature, and OB studies that examine aspects of voice such as complaining or whistleblowing have been streamed down another path and labelled "justice-oriented" voice. Klaas et al. (2012) provides a broader review than Morrison (2011) in the sense that it incorporates the smaller stream of justice oriented voice and seeks to illustrate in what way the two types of voice can be seen to impact the antecedents of voice. For example, Klaas et al. (2012: 327-8) note the "pure form" pro-social voice shows an identity of interests between worker and management which lessens the risks of raising voice whereas justice-oriented voice is more about wrongdoing and restitution. In this regard, Klaas et al. (2012: 336) also acknowledge other literature like that on unions but only to say that unions reduce the perception of risk to employees of raising voice in a formal context. In general, the Klaas et al. (2012) review is less concerned with the role of institutional structures, such as unions or works councils, and more concerned with the distinction between formal versus informal voice, focussing mainly on whistle blowing (principled organisational dissent) and grievance procedures as forms of formal voice. Importantly, however, while Klaas et al. (2012) specifically discusses the importance of justice-oriented voice, they see this as a form of dealing with disputes or correcting wrongdoing, or of voice as being a way employees can exact revenge. This view of voice does not accord with the ER notion that voice reflects the differences of interest between workers and owners/managers or that voice can simply be a means of employee selfdetermination. 
Accordingly, the notion of voice identified by Van Dyne and LePine (1998) has driven much of the empirical research on discretionary voice behaviour (as is noted by Morrison 2014: 176). In short, the OB conception of voice has consolidated around the pro-social definition so that the recently integrated OB definition of employee voice provided by Morrison (2011: 375) is: "discretionary communication of ideas, suggestions, concerns, or opinions about work-related issues with the intent to improve organizational or unit functioning". Thus, the current OB-centric, one might call it managerial perspective, sees voice as being about verbal communication, chosen by an individual, which is constructive to management. Management encourages voice to emerge on their terms, setting the parameters of what is and is not permissible voice behaviour according to employer interests (Donaghey et al. 2011). Morrison (2011: 375) explicitly rules out voice as a mechanism "simply to vent or complain" and therefore excludes any conceptualisation of employee voice based on interests other than those of the employer. By excluding complaints, the OB perspective tends to leave out what the ER perspective views as an essential component of voice.

The OB literature attaches specific requirements to voice behaviour under its narrow conceptualisation. It must benefit more than just the person who raises their voice (Van Dyne et al. 2003), and it is offered to bring positive change rather than for the airing of grievances (Morrison 2011); although little consideration is given to the idea that dealing with grievances (or indeed deviant behaviour) might produce positive change. Voice then is only useful if it benefits the work unit or the organisation as a whole, particularly in terms of improved productivity. A strong emphasis in the OB literature is that studies of voice should explain the preconditions for this benefit and measure its impact. In other words, the research agenda is aimed squarely at explaining what features of the workplace lead individual employees to decide to raise their voice, rather than choosing to remain silent, and what impact this behaviour has on the organisation.

If management research operates from a view that voice is a useful activity if it can provide benefit to the organisation, it also conceptually narrows voice into such terms and excludes other perspectives. In her wide ranging review of the various literatures on voice, Morrison (2011: 381) acknowledged "a rich literature” within ER (she refers to it as industrial labor relations) and HRM, but went on to dismiss this from her review because:

"They have not considered discretionary voice behaviour, or the causes or consequences of this behaviour. In sum, as these various literature streams define voice in a way that does not closely match current conceptualizations, I exclude them from this review". 
Here, paradoxically, ER studies are referred to as voice studies in a literature review of voice which is meant to be encompassing, but are then deemed not to be studies of voice because they do not examine discretionary, individual voice behaviour which are the current conceptualisations, according to Morrison (2011). So what she means by the current conceptualisations of voice is current conceptualisation within OB. However, excluding ER in this way seems to be unproductive and at odds with Morrison's (2011) stated intention to identify gaps and unresolved issues in the voice literature and to 'integrate' research and provide directions for future studies. It is also in danger of being charged with a conventionalist twist.

Our claim here is that voice has been reframed in OB to suit a narrow managerial bias that requires that the articulation of voice should meet certain pre-requisites and be of benefit to management. Donaghey et al. (2011) have criticised the way that OB researchers use the voice construct to claim that by allowing employees to raise different, and even possibly competing viewpoints, management is creating a climate of organisational pluralism. As these authors point out, the ability to offer views that are different to management, so long as those views assist in improving the quality of decision making and organisational performance, falls well short of the mark, for a "genuine pluralism rests upon social values which recognise the right of employees to an effective voice in their own destiny, regardless of the consequences for management” (Donaghey et al. 2011: 55).

In defining voice as a pro-social behaviour, voice becomes framed as an activity that is linked to organisational citizenship. As Klaas et al. (2012: 327) notes "in its pure form, pro-social voice is framed as benefiting the organization by improving processes and performance (Van Dyne et al. 2003). As such the literature has given little attention to the potential for conflict of interest between the employee and the recipient of the message." Accordingly, voice is considered something employees do to help the organisation rather than to build an identity for themselves, which is separate to and distinct from management. Not only does this contradict the prevailing view of ER that voice is an expression of employees' desire to co-determine work rather than just raise interesting suggestions for improved processes, it also ascribes a very simplistic set of motives to acts of organisational citizenship. Indeed, Grant and Mayer (2009) caution against drawing a direct link between pro-social motives and organisational citizenship, arguing that employees who have both pro-social and strong impression management motives will exhibit higher levels of 'affiliative' citizenship and lower levels of 'challenging' citizenship. This would tend to indicate that it is difficult to disentangle instrumental voice behaviour (employee impression management motives) from expressions of pro-social behaviour that are truly other-oriented. It also has an important implication for voice, as workers who have pro-social motives may be guided by stronger impression management motives, and suppress feelings of empathy and concern for others, if raising voice means 
challenging supervisors and the status quo (Grant and Mayer 2009). What this suggests is that to look at voice as only pro-social misses the point that individual employees may have a mix of motives in raising voice, or indeed choosing silence. Those who raise voice may do so in a positive manner, but this may have more to do with seeking to create a positive impression of oneself, rather than to improve conditions for others. As Klaas et al. (2012: 329) put it, "Efforts to offer constructive suggestions may thus be driven by a desire to be recognised for having competencies and skills that are important to the organisation". Such behaviour would seem to satisfy one requirement of the OB conception of pro-social voice as not being about airing grievances, but fails another requirement of pro-social behaviour, in that impressionistic motives that underlie voice do not indicate other-oriented behaviour. This type of contradiction is not problematised in the OB literature on voice.

As we have noted, the focus of the majority of $\mathrm{OB}$ research on voice looks at the antecedents of individual voice decisions and outcomes. OB studies ask what prompts an employee to raise voice in a pro-social manner, and what factors within organisations are likely to promote or impede voice outcomes. In one such study, McClean et al. (2013) surveyed a large number of employees in over 100 stores within a single US restaurant chain. Seeking to examine only pro-social voice - which they defined as "suggestions hav[ing] broad benefit rather than just improvement in the speaker's well being” (McClean et al. 2013: 531), they carefully coded responses to open ended questions to screen out selfish, individual responses that did not meet this test. The following are provided by these authors as examples of their categorisations:

Pro-social - "Not paying your workers that have been here for 3+ years \$7-8. Yet new hires sometimes walk through the door making $\$ 8.50$ and $\$ 9$ and up - so this isn't right. We as a company need to work on paying our old hires more money for their jobs. Let's make a change”.

Not Pro-social - "I have worked for the company for 3 years. I make \$7.25 an hour and I do the EOD, inventory, and deposits. Why is this? I feel I am not important to this company and what I do here means squat”. (McClean et al. 2013: 532).

These categorisations seem curious as both statements represent concern that experienced employees receive inadequate and unfair payment. It is possible that these statements could be rewritten as follows: the pay for experienced employees should be better (pro-social); my pay as an experienced employee should be better (not pro-social). We highlight this example of OB research because it points to a fundamental problem in seeking to define voice as an individual, pro-social behaviour, which is that drawing boundaries between individual and collective workplace behaviour as self or other oriented, is inherently fraught. In the ER field, voice is often seen as an expression of real or perceived concerns about matters that relate to equity and fairness. What is fair and equitable are 
normative judgements that are fundamentally collective in nature. In other words, individuals (employees) make judgements about themselves, but they often do so in relative rather than absolute terms (Baldamus 1957). In this sense, even if voice is self-directed (about an individual's experience of work and employment), it is also other-oriented (felt in relation to other workers' experience).

\section{The value of ER voice}

As we noted earlier, according to Morrison (2011), ER studies of voice do not fit the conception of voice because they do not consider discretionary employee voice behaviour. Morrison (2011) acknowledges ER studies but dismissed them because they are limited to explaining the nature and type of institutional mechanisms that provide workers with voice. Therefore, underlying the exclusion of ER studies in the OB conception of voice is an assumption that institutional mechanisms do not shape employee behaviour. The contention we offer here is that ER voice literature highlights the important influence of institutional context on individual voice behaviour (Dundon et al. 2004; Wilkinson et al. 2004). In OB studies of voice however, the context for individual behaviour does not extend far beyond the relationship between the individual worker and management (both supervisors and higher leaders). An awareness of this limitation can be seen in the work of McClean et al. (2013) who make the valuable point that by definition, pro-social behaviour is collective, in that it extends beyond the individual actor to the influence of that behaviour on the work group or the firm. Despite this however, these authors concede that there has been little effort to understand work group behaviour in the OB voice literature, nor the complex relationship between the effort by employees to raise voice and the way that voice is acted on by managers. In an earlier study, Detert and Burris (2007: 881) more broadly acknowledged that a limitation of their work was that it was set in one specific context and that a similar study of leader reactions to voice in a different context might yield very different patterns of voice. These authors were usefully highlighting that in a low skill, service sector workplace, the consequences of raising voice might be considerably lower for employees who could transfer employment to other firms without much cost, than for employees in other settings where substantial investment in firm specific skills tied them to their employer. In such settings, logic would follow that for voice to have a chance to flourish, management would need to demonstrate much more openness.

Of course, one could say that ER studies of voice are predominantly interested in analysing the institutional structures of voice without regard to their impact on employee behaviour or on organisational outcomes, and thus are a mirror image of OB studies which do the reverse (Marsden 2013). We acknowledge that ER research has tended to focus on institutional structures, but we would dispute the view that the interest has stopped there. Empirical research on the role of works councils 
in Germany found that this structure of employee voice can be considered 'organisationally efficient' because works councils played a largely supportive role in the provision of training and also had a measurably positive effect in reducing layoff and quit rates (Backes-Gellner et al. 1997; Sadowski et al. 1995). These same studies found that a high degree of mutuality existed between the interests of employers and works councils in the provision of voice, which stemmed from the institutional separation of this structure of voice from the role that unions play in pay bargaining and industrial action. The legal restriction on work councils from engaging in pay bargaining and industrial action, and indeed the legal obligation of works councils to work in the interests of the firm as well as its employees, provides an institutional structure that allows voice to be raised in a way that is less adversarial and potentially more 'pro-social' than where it is absent (Marsden 1999: 226-227; see also Freeman and Lazear 1995). According to Backes-Gellner et al. (1997: 329), these features of the German system make works councils an 'institutionally efficient' arrangement.

In making these remarks, we are aware that there is a danger of idealising European works councils and other union collective bodies as they represent an almost prima facia case for a more extensive and deeper voice channel than other voice processes. In their classic study, Popitz et al. (1969) revealed the concerns of German workers that works councillors formed too close a relationship with management. The views of councillors, once elected, were not 'those of us' but reflected values of 'those up there'. Equally, it is too easy to dismiss other management-led structures as a bleak house without fully unpicking and examining employer motives for such voice, the type of mechanisms used, and the needs of employees. In other words, there is a danger of categorising all non-union representation or voice as ineffectual and union representation as very effective without investigating the detail of non-union voice empirically (Dundon and Rollinson 2011).

Evidence of the impact of ER structures on individual voice preferences is provided by Freeman and Lazear (1995) in relation to work councils, and Marsden (2013) in a study comparing voice structures and voice outcomes in France and the United Kingdom. Freeman and Lazear (1995) hypothesise that works councils can enhance the prospect of employee voice for the benefit of workers and management, under certain circumstances. These authors found that councils can improve the prospect of information sharing on the part of workers where councils have consultation rights because workers perceive that these rights will raise the likelihood that workers will also benefit from information sharing. Crucially, benefits to both parties accrue from information sharing where workers have information that management does not possess, and where the benefits of gaining that information exceed the cost of the additional time incurred in the consultation process. Here, it was specifically noted that consultation becomes costly the longer the process goes on, and also, in 
slowing decision making, formal consultation can potentially narrow the range of decision options for management. The benefits of this particular structure must then be weighed against potential costs.

Marsden (2013) adds a comparative element to this research by contrasting the UK negotiated model in which individual and collective voice are substitutes for each other, with the French 'rights based' model where employment law guarantees a role for works council representation, and where individual and collective voice are compatible. Marsden (2013) finds that in the UK context, shop stewards tend to collectivise individual voice because of their links to unions and the need to mobilise voice into collective issues/grievances, whereas in the rights based model, delegates are much more able to support individual voice because of their guaranteed status under the law, and as a result, individual and collective voice can more easily coexist. Marsden (2013) also found that workers have more capacity to engage in voice where they have marketable skills, and this may indeed prompt employers to engage in management-led voice because management may fear that without voice, disagreements can lead to higher levels of costly exit and that collective voice could potentially give unions greater bargaining power. Here again, however, works councils may be supported (rather than unions in other countries) because they are legally restricted from engaging in pay bargaining.

In work on the Australian experience of voice Benson (2000: 457) reports that union presence did not inhibit other HRM forms of voice and indeed employees in unionised workplaces had significantly more voice mechanisms than those in non-union workplaces. In the United States, Black and Lynch (2004: F113) noted that workplace innovation, especially when it has occurred in unionised establishments, is positively associated with labour productivity. These authors inferred that this strong effect in unionised workplaces could be the result of workers being more willing to participate in employee involvement programmes and voice (in a pro-social way) if they feel the union will protect their employment security.

Given these various findings, we would argue that ER studies have much to offer in explaining employee (as well as employer) voice preferences and behaviours. ER studies have sought to explain what features of the pattern of employee relations in different settings give rise to extensive or limited forms of voice. What they show in general is that voice is likely to be more expansive or have more depth where it is employee-initiated and where it is backed by statutory protections that mandate a role for employee voice in organisational decision-making. Management-initiated voice schemes on the other hand are likely to provide voice on terms dictated by management, which are often limited to opening up lines of communication, and potentially extending voice into the provision of consultation in matters of (employer) decision-making. However, management voice schemes do not generally offer workers forms of voice which enable them to contest decisions. The reason for this is 
quite obvious, as Freeman and Lazear (1995: 48) remind us that "Co-determination can greatly increase worker power". However, as these authors and others who have studied works councils note, where councils are formally removed from pay bargaining, the prospect of employees using voice mechanisms to extract economic rent is greatly reduced. In summarising the contribution of these ER studies we would assert that they do deserve consideration, even within the narrow confines of OB voice research, because they provide an essential backdrop to "the predominant focus of much of the empirical research on voice [which] has been on identifying factors that increase or decrease the amount of voice behaviour that an employee engages in..." (Morrison 2011: 385). In short, there are some possible complementarities between ER and OB voice research. Thus, while the OB literature focuses on specific employee behaviors on an individual level whereas the ER literature does not tend to analyze, measure, or observe individual behaviours or actions, what ER does explain is the context in which those behaviours and actions take place and what makes them more likely to take place.

The OB literature is also interested in how effective voice can be and what role managers, as voice targets, play in this process. Therefore, management style and in particular, whether managers are receptive to suggestions and feedback, is an important determinant of voice. The ER lens would again seem to help provide answers, such as showing that in unionised contexts, or where formal voice mechanisms are mandated by law, workers have greater opportunity to voice and contest management decisions. This is a limitation of the OB research which does not explain how context shapes and constrains managers' choices in dealing with voice, and how management style is influenced by context. Institutional factors that provide voice also make voice more likely, in that they offer protection against repercussions for employees who might otherwise, individually, choose silence. A related point is that the presence of formal voice mechanisms may also lead to increased informal voice, because formal mechanisms create a climate in which voice overall can flourish (Marchington 2007; Marchington and Suter 2013). Yet, in excluding ER voice because it is focussed on mechanisms rather than individual behaviour, the OB research cannot gauge the importance of a 'spill over' effect between formal and informal voice.

\section{Silence is also golden: voice, silence and pro-social behaviour}

An interesting development in the $\mathrm{OB}$ literature has been the extension of the voice construct to incorporate employee silence. ER researchers have also begun to examine silence as part of their analysis of voice (Donaghey et al. 2011). Both literatures argue that silence is not just the antithesis of voice in the sense that it denotes a lack of voice, but that silence can also be the conscious decision to withhold voice. Efforts by OB scholars to better understand silence are encouraging because much less is known of silence than voice, and in exploring silence these studies have also added to our 
understanding of the dynamic between exit and voice. Indeed, it could be argued that the original EVL and exit/voice frameworks were simplistic in that they did not consider that workers might choose both voice and exit (McClean et al. 2013: 525) and that it is also possible that workers might choose to be silent and stay, rather than exit. Yet, as alternative potential behaviours to voice, silence and exit are both underlined by feelings of frustration and futility. In that sense, the exit/voice framework continues to have salience for contemporary voice studies.

In an effort to develop the nascent work on silence Van Dyne et al. (2003) extended the existing OB conceptualisation of silence by incorporating pro-social behaviour. Previous OB research on silence included two types of behaviour - one being defensive silence; aimed at protecting the individual, and the other being acquiescent silence; which denoted a lack of voice stemming from futility. To these was added pro-social silence, which these authors define as actions (in not voicing information and opinions) that are proactive, positive, and other-oriented (Van Dyne et al. 2003: 1368).

Like the OB conceptualisation of voice, this OB view of silence also has apparent limitations. In distinguishing between these types, the conceptualisation limits the possibility that silence might result from a combination of all three factors. Employees might be fearful of the repercussions of speaking up, but at the same time they might be de-motivated, and they might also believe that speaking up is futile because in past instances they perceived that voicing ideas and opinions led to victimisation and/or no change. In such instances, silence would be defensive in terms of a perceived fear of personal repercussions, pro-social in as much as there is a fear of repercussions for others, and acquiescent in that there is also a perception that voice is futile.

The problem with the OB conceptualisation of silence is that it draws a hard line between defensive behaviour, which is framed as protecting the individual, and pro-social behaviour, which is framed as helping others. However, it seems logically possible for defensive silence to be an act to protect others in instances where speaking up might cause collective harm. In this way, defensive silence would meet the definition of pro-social behaviour, which is that it is proactive, positive and other-oriented. While Van Dyne et al. (2003: 1362) acknowledge that the relationship between silence and voice "often represents a complex amalgam of motives" and that "they do not intend for [their] framework to be comprehensive", these qualifying statements are not framed as specific limitations of their model which posits three mutually exclusive silence behaviours. Interestingly, the notion of 'mixed motives' was picked up in the review of voice literature by Klaas et al. (2012), who provide a scenario in which an employee suggestion to formalise a process of assigning work is pro-social, in that it leads to a more efficient process, but at the same time reveals another motive, in that the effect of the change is to limit management discretion in the allocation of work. 
OB research on silence, just like OB voice research, is also limited because it explicitly frames voice as discretionary, individual behaviour. There are few OB studies, one being Morrison and Milliken (2000), that underscore the collective aspects of voice by showing how employees remain fearful of exercising their voice in organisational cultures of silence. Even when OB does look at collective behaviour, it is looked at through the lens of group voice climate, that is, the relationship between the group and the supervisor but disconnected from the organisation and regulatory structures (see, for example, Detert and Treviño 2010; Frazier and Bowler 2012; Frazier and Fainshmidt 2012; Morrison et al. 2011). Both Pinder and Harlos (2001) and Harlos (2001) also allude to a culture of silence when they talk about voice falling on 'deaf ears'. Taking this point further, Donaghey et al. (2011) argue that $\mathrm{OB}$ literature on employee silence is deficient because it seeks to ask why employees choose silence when, in many instances, employee silence stems from a fundamental inability to exercise voice. These ER authors question whether workers choose silence or whether in fact that choice is made for them. Again, this highlights the value of ER research that situates voice, and silence, within its employment relations context, and in doing so, highlights the importance of power structures and draws links between voice ‘climate’ and voice outcome (Pyman et al. 2006).

\section{Where to from here?}

This review has argued that the OB approach to both employee voice and silence proceeds from a narrow conception of these phenomena which limits the capacity of OB studies to fulfil their research agenda, to be able to predict the determinants of voice and silence and measure their impact on employee and organisational performance. OB research sees voice as operating in a world where organisational actors are divorced from an institutional context composed of such things as labour law regulation, unionisation, and company policies or statutory regulations that mandate certain forms of employee involvement (Godard 2014). OB voice studies are also preoccupied with explaining individual traits that would lead some employees to 'choose' voice, while others 'choose' to remain silent. Equally important in this research are the traits of individual managers, including their openness to voice, in terms of determining what reception voice will get. Within this framework there is blindness to systemic issues of power.

The OB literature on voice also contains value-laden assumptions, based on a presumed identity of interests, such as what is good for the firm is good for the employee and that employees naturally want to speak up in ways that benefit management. These assumptions are not properly tested in the literature, which means that their conception of voice as a pro-social activity is not contested. We need look no further than the classic work of Roy $(1952,1954)$ for a useful corrective to these 
assumptions. In his famous participant observation study, Roy (1952: 430; 1954: 265) challenged the view that employee soldiering resulted from a lack of understanding on the part of work groups of the "economic logics of management". The workers in the machine shop were in fact highly alert to their economic interests, which differed from those of management, in restricting output. The author, as an employee, was actually scolded by workmates on many occasions for working too hard because the work group reasoned that the inevitable result of turning in excess earnings would be a retiming of the work and a consequent cut in the piece rate. Although this soldiering behaviour advanced the interests of the work group, it would be hard to imagine that OB would see this as pro-social behaviour, because it clearly was intended to frustrate the interests of management. In Roy's $(1952,1954)$ study, individual employee behaviour was forged through a highly social process, but one where employees came to view their identity and interests as distinct from, and in opposition to, that of management.

As stated at the outset of this paper, there is some acknowledgement in the OB literature that voice is more than just a pro-social activity and this is highlighted in the smaller, justice-oriented stream. Interestingly, the meta-review of voice by Klaas et al. (2012) calls for a greater understanding of this type of voice so as to identify the 'critical determinants' that would lead employees to engage in justice-oriented voice or pro-social voice. However useful this might be in raising the need to look beyond pro-social voice, where studies such as this research are still limited is in the use of a frame of reference that sees justice-oriented voice as being fundamentally about the correction of mistreatment or injustice, rather than about the assertion of employee interests that are different from those of management. Implicit in this framing is the negative connotation of formal voice being about identifying wrongdoing. Thus, Klaas et al. (2012: 337-339) have a section of their review devoted to "considering the dark side of voice". In this section they discuss forms of voice that are counterproductive to the organisation which include attempts to restore justice by causing harm to the organisation, including engaging in acts of revenge. An ER perspective on this would see employee efforts to cause harm to the organisation as appearing at the far end of the behaviour spectrum, and usually engaged in only after more constructive avenues of voice have been explored or exhausted. Consistent with the exit/voice framework, ER would also say that the assertion of employee interests may well be interpreted as criticism of management, but may nevertheless lead to productivity enhancing outcomes if for no other reason than an inability to voice may lead to productivity lowering outcomes such as higher levels of de-motivation, absenteeism and turnover, as highlighted above in the case of works councils. Here, ER might also draw on the classic work of Wright Mills (1948) who invoked the notion of unions as managers of discontent, harnessing conflict but also moderating its disruptive effect. 
Very slowly it seems there may be developments that suggest that the OB field sees the need to engage with other literatures to get a fuller picture of voice. Klaas et al. (2012: 322) acknowledge that "the different voice literatures have developed, for the most part, in isolation from one another". According to Brinsfield (2014), the OB literature lacks an integrative framework to make sense of the extensive body of related literatures on voice. Therefore, “OB scholars need to stay abreast of relevant new research from a wide variety of sources. We also need to thoughtfully questions [sic] our paradigmatic assumptions surrounding voice and silence which may unwittingly constrain our thinking" (Brinsfield 2014: 128). This view is echoed by Kaufman (2014b), who argues that "no field is free of excessive specialisation and narrowness of approach; however, the OB-related segment of the voice literature seems particularly isolated from the historical roots of the subject and theories and findings in other research traditions". Given that OB voice studies increasingly appear to claim to represent management, rather than just $\mathrm{OB}$, it is important to ensure that the narrow $\mathrm{OB}$ conception of voice does not become an accepted unifying framework for voice research - not at least without some debate!

\section{Conclusion}

This review has highlighted a number of deficiencies in the OB conception of voice as predominantly pro-social, individual behaviour.. According to OB research, individuals choose to exercise pro-social voice (and voice is only considered that which is pro-social), but that choice is made in the context of formal and informal voice alternatives, with only the informal channel considered pro-social.

Overall our paper sets out our concern at the impoverished definition of voice currently being used. It is not an exaggeration to suggest that $\mathrm{OB}$ is in danger of making illegitimate that which most scholars outside the OB field - not just ER ones - would regard as voice. Is there a hint of doublethink in the contention that the notion of voice, which is only defined as pro-social, can lead to better lives and conditions only as agreed to by management? What would happen if this term was redefined by politicians such that voice is only voice if it benefits the party in power?

While we agree that there is considerable scope for gaining the cooperation of employees in voicing, as the employment relationship is not 'zero-sum', this does not negate the argument that there are inherent conflicts over the costs and benefits of the employment relationship (Wilkinson and Willmott 1995). Paradoxically, OB disenfranchises workers as active agents with a legitimate claim to have their voices heard. Rather, they are to merely be the functionaries of a pre-established scheme in a hegemonic climate which emphasises management’s right to manage (Nichols 1986). 
We also observe that the mainstream ER view has, in its own way, narrowed employee voice by seeking to identify voice as being only about airing and redressing employee grievances (see Budd 2014). Thus, just as OB research has ignored aspects of voice that they see as 'complaining', ER research has been too focused on dissatisfaction. As we have noted, if voice is seen as a means of selfdetermination, it can be present without being attached to a specific dissatisfaction, and we believe that ER needs a conception of voice that includes self determination, as well as encompassing both individual and collective, informal and formal, and communicative and structural components of voice. However, if the ER and OB fields are able to be better integrated, we also maintain that a crucial distinction remains; for the basis of the ER perspective is that it sees voice as being grounded in the asymmetrical employment relationship.

Furthermore, Budd and Zagelmeyer (2010) remind us that employee voice is not simply a private affair; a case of those employers who believe it is in their own interest to provide vehicles for employee voice doing so, while others decide against it. Rather, they argue that employee voice can reach far beyond competitiveness and profitability and can also shape the psychological and economic well-being of individuals, the physical and emotional health of a community's families, and the quality of a country's democracy. As a consequence, employee voice has important implications for public policy through governmental regulation of the employment relationship. In addition, voice in the workplace allows for workers to develop skills and values, which then have a role in broader society (Foley and Polanyi 2006).

Our contention is that employee voice is too important to be simply seen as a vehicle to assist management on management terms. The danger of not challenging the OB conception of voice is that the voice term might be degraded in Orwellian, newspeak fashion.

Acknowledgments

We would like to thank the two anonymous referees, the editor and Paula Mowbray for their helpful comments on our paper. 


\section{References}

Backes-Gellner, U., Frick, B. and Sadowski, D. (1997). 'Codetermination and personnel policies of German firms: the influence of works councils on turnover and further training'. The International Journal of Human Resource Management, 8(3): 328-347.

Baldamus, W. (1957).'The relationship between wage and effort’. Journal of Industrial Economics, July: 192-201.

Benson, J. (2000). ‘Employee voice in union and non-union Australian workplaces’. British Journal of Industrial Relations, 38(3): 453-9.

Black, S. E. and Lynch, L. M. (2004). 'What's driving the new economy?: The benefits of workplace innovation’. The Economic Journal, 114(493): F97-F116.

Boxall, P., Haynes, P. and Freeman, R. (2007). ‘Conclusion: what workers say in an anglo-American world'. In Freeman, R., Boxall, P. And Haynes, P. (eds), What Workers Say in the AngloAmerican Workplace. New York: Cornell University Press, pp. 206-220.

Brinsfield, C. (2014). 'Employee voice and silence in organizational behaviour'. In Wilkinson, A., Donaghey, J., Dundon, T. and Freeman, R. (eds), The Handbook of Research on Employee Voice. Cheltenham: Elgar Press, pp. 114-135.

Budd, J. (2004). Employment with a Human Face: Balancing Efficiency, Equity, and Voice. .Ithaca: ILR Press.

Budd, J. (2014). 'The future of employee voice’. In Wilkinson, A., Donaghey, J., Dundon, T. and Freeman, R. (eds), The Handbook of Research on Employee Voice. Cheltenham: Elgar Press, pp. 477-487. 
Budd, J. and Zagelmeyer, S. (2010).'Public policy and employee participation’. In Wilkinson, A., Gollan, P., Marchington, M. and Lewin, D. (eds), The Oxford Handbook of Participation in Organizations. Oxford: Oxford University Press, pp. 476-504.

Charlwood, A. and Pollert, A. (2014). ‘Informal employment dispute resolution among low-wage non-union workers: does managerially initiated workplace voice enhance equity and efficiency?’ British Journal of Industrial Relations, 52(2): 359-386.

Detert, J.R. and Burris, E.R. (2007). 'Leadership behavior and employee voice: is the door really open?’ Academy of Management Journal, 50(4): 869-84.

Detert, J. R. and Treviño, L. K. (2010). 'Speaking up to higher-ups: How supervisors and skip-level leaders influence employee voice’. Organization Science, 21(1): 249-270.

Donaghey, J. Cullinane, N. Dundon, T. and Wilkinson, A. (2011). 'Reconceptualising employee silence: problems and prognosis’. Work, Employment and Society, 25(1): 51-67.

Dundon, T. and Rollinson, D. (2011). Understanding Employment Relations, $2^{\text {nd }}$ edition. Berkshire: Mcgraw-Hill.

Dundon, T., Wilkinson, A., Marchington, M. and Ackers, P. (2004).'The meanings and purpose of employee voice’. International Journal of Human Resource Management, 15(6): 149-70.

Foley, J. and Polanyi, M. (2006). 'Workplace democracy: why bother?' Economic and Industrial Democracy, 27(1): 173-91.

Frazier, M. L. and Bowler, W. M. (2012). 'Voice climate, supervisor undermining, and work outcomes: A group-level examination'. Journal of Management. In press. DOI: 10.1177/0149206311434533. 
Frazier, M. L. and Fainshmidt, S. (2012). 'Voice climate, work outcomes, and the mediating role of psychological empowerment: A multilevel examination’. Group \& Organization Management, In press. DOI: 10.1177/1059601112463960.

Freeman, R. and Medoff, J. (1984). What Do Unions Do? New York: Basic Books.

Freeman, R., Boxall, P. and Haynes, P. (eds) (2007). What Workers Say: Employee Voice in the Anglo-American Workplace. Ithaca: Cornell University Press.

Freeman, R.B. and Lazear, E.P. (1995). ‘An econometric analysis of works councils’. In Rogers, J. and Streeck, W. (eds) Works councils—consultation, representation and cooperation in industrial relations. Chicago: University Press, pp 27-52.

Fuller, J. B., Marler, L. E. and Hester, K. (2006). 'Promoting felt responsibility for constructive change and proactive behavior: Exploring aspects of an elaborated model of work design'. Journal of Organizational Behavior, 27(8): 1089-1120.

Godard, J. (2014). The psychologization of employment relations? Human Resource Management Journal, 24(1): 1-18

Gollan, P, Kaufman, B, Taras, A. and Wilkinson, A (eds) (2014). Voice and Involvement at Work: Experience with Non-Union Representation Across Three Continents. New York: Taylor and Francis.

Gomez, R., Bryson, A. and Willman, P. (2010). 'Voice in the wilderness?: the shift from union to non-union voice in Britain'. In Wilkinson, A., Gollan, P., Marchington, M. and Lewin, D. (eds). The Oxford Handbook of Participation in Organizations, Oxford: Oxford University Press, pp. 383-406. 
Grant, A. M., \& Ashford, S. J. (2008). 'The dynamics of proactivity at work'. Research in Organizational Behavior, 28: 3-34.

Grant, A.M. and Mayer, D.M. (2009). 'Good soldiers and good actors: Prosocial and impression management motives as interactive predictors of affiliative citizenship behavior'. Journal of Applied Psychology, 94(4): 900-12.

Greenberg, J. and Edwards, M. (eds) (2009). Voice and Silence in Organizations. Bingley, UK: Emerald Group Publishing.

Harley, B. (2014). 'The one best way? 'Scientific' research on HRM and the threat to critical scholarship’. Paper presented to International Labour Process Conference, Kings College, London.

Harlos, K. (2001). 'When organizational voice systems fail: more on the deaf-ear syndrome and frustration effects’. The Journal of Applied Behavioral Science, 31(3): 324-42.

Hirschman, A. (1970). Exit, Voice, and Loyalty: Responses to Decline in Firms, Organizations, and States. Cambridge: Harvard University Press.

Kaufman, B. (2014a). 'Employee voice before Hirschman: its early history, conceptualization, and practice'. In Wilkinson, A., Donaghey, J., Dundon, T. and Freeman, R. (eds), The Handbook of Research on Employee Voice. Cheltenham: Elgar Press, pp. 17-35.

Kaufman, B. (2014b). 'Theorizing determinants of employee voice: An integrative model across disciplines and levels of analysis’. Human Resource Management Journal. In press.

Kaufman, B. and Taras, D. (2010). 'Employee participation through non-union forms of employee representation'. In Wilkinson, A., Gollan, P., Marchington, M. and Lewin, D. (eds), The Oxford Handbook of Participation in Organizations. Oxford: Oxford University Press, pp. 258-285. 
Klaas, B., Olson-Buchanan, J. and Ward, A.-K. (2012). 'The determinants of alternative forms of workplace voice: an integrative perspective’. Journal of Management, 38(1): 314- 45.

Lam, C. F., \& Mayer, D. M. (2013). 'When do employees speak up for their customers? A model of voice in a customer service context’. Personnel Psychology. In press. DOI: 10.1111/peps.12050.

Liang, J., Farh, C. I. and Farh, J. L. (2012). 'Psychological antecedents of promotive and prohibitive voice: A two-wave examination’. Academy of Management Journal, 55(1): 71-92.

Liu, W., Zhu, R. and Yang, Y. (2010). 'I warn you because I like you: Voice behavior, employee identifications, and transformational leadership’. The Leadership Quarterly, 21(1): 189-202.

Marchington, M. (2007). ‘Employee voice systems’. In Boxall, P., Purcell, J. and Wright, P. (eds), The Oxford Handbook of Human Resource Management. Oxford: Oxford University Press, pp. 231-250.

Marchington, M. and Suter, J. (2013). 'Where informality really matters: Patterns of employee involvement and participation (EIP) in a non-union firm’. Industrial Relations, 52: 284-313.

Marsden, D. (1999). A Theory of Employment Systems: Micro-Foundations of Societal Diversity. Oxford: Oxford University Press.

Marsden, D (2013). 'Individual voice in employment relationships: a comparison under different forms of workplace representation’. Industrial Relations, 52: 221-258.

McClean, E., Burris, E.R. and Detert, J.R. (2013). 'When does voice lead to exit? It depends on leadership’. Academy of Management Journal, 56(2): 525-48.

Morrison, E.W. and Milliken, F.J. (2000). 'Organizational silence: a barrier to change and development in a pluralistic world'. Academy of Management Review, 25(4): 706-25. 
Morrison, E. (2011). 'Employee voice behavior: integration and directions for future research'. Academy of Management Annals, 5: 373-412.

Morrison, E. (2014). 'Employee Voice and Silence’. Annual Review of Organizational Psychology and Organizational Behavior, 1: 173-197.

Mowbray, P., Wilkinson, A. and Tse, H. (2014). ‘An Integrative Review of Employee Voice: Identifying a Common Conceptualisation and Research Agenda’. International Journal of Management Reviews. In press. DOI: 10.1111/ijmr.12045.

Nichols, T. (1986). The British Worker Question: A New Look at Workers and Productivity in Manufacturing. London: Routledge and Kegan Paul.

Nikolaou, I., Vakola, M. and Bourantas, D. (2008). 'Who speaks up at work? Dispositional influences on employees' voice behavior'. Personnel Review, 37(6): 666-679.

Pinder, C.C. and Harlos, K.P. (2001). ‘Employee silence: quiescence and acquiescence as responses to perceived injustice'. Research in Personnel and Human Resources Management, 20: 331-69.

Popitz, H., Bahrdt, H., Jueres, E. and Resting, A. (1969). 'The worker’s image of society'. In Burns, T. (ed), Industrial Man: selected readings. Harmondsworth: Penguin Books, pp. 281-324.

Pyman, A., Cooper, B., Teicher, J. and Holland, P. (2006). 'A comparison of the effectiveness of employee voice arrangements in Australia’. Industrial Relations Journal, 37(5): 543-59.

Roy, D. (1952). 'Quota restriction and goldbricking in a machine shop’. American Journal of Sociology, 57: 478-485.

Roy, D. (1954). 'Efficiency and "the fix": Informal intergroup relations in a piecework machine shop'. American Journal of Sociology, 60(3): 255-266. 
Sadowski, D., Backes-Gellner, U. and Frick, B. (1995). 'Works Councils: Barriers or Boosts for the Competitiveness of German Firms?’. British Journal of Industrial Relations, 33(3): 493-513.

Tangirala, S., Kamdar, D., Venkataramani, V. and Parke, M. (2013). 'Doing right versus getting ahead: The effects of duty and achievement orientations on employees' voice'. Journal of Applied Psychology, 98(6): 1040.

Tangirala, S. and Ramanujam, R. (2008). 'Employee silence on critical work issues: The cross level effects of procedural justice climate’. Personnel Psychology, 61(1): 37-68.

Tangirala, S., and Ramanujam, R. (2008b). 'Exploring nonlinearity in employee voice: The effects of personal control and organizational identification'. Academy of Management Journal, 51(6): 11891203.

Van Dyne, L., Cummings, L.L. and McLean Parks, J.M. (1995). 'Extra-role behaviors: In pursuit of construct and definitional clarity (a bridge over muddied waters)'. Research in Organizational Behavior, 17: 215-215.

Van Dyne, L. and LePine, J.A. (1998). 'Helping and voice extra-role behaviors: Evidence of construct and predictive validity’. Academy of Management Journal, 41(1): 108-119.

Van Dyne, L., Ang, S. and Botero, I. (2003). 'Conceptualizing employee silence and employee voice as multidimensional constructs’. Journal of Management Studies, 40(6): 1359-92.

Wang, Y. D. and Hsieh, H. H. (2013). ‘Organizational ethical climate, perceived organizational support, and employee silence: A cross-level investigation’. Human Relations, 66(6): 783-802.

Wilkinson, A. and Fay, C. (2011). New times for employee voice?' Human Resource Management, 50(1): 65-74. 
Wilkinson, A. and Willmott, H. (1995). Making Quality Critical: New Perspectives on Organizational Change. London: Routledge.

Wilkinson, A., Dundon, T., Marchington, M. and Ackers, P. (2004). 'Changing patterns of employee voice: Case studies from the UK and Republic of Ireland'. The Journal of Industrial Relations, 46(3): 298-322.

Wilkinson A, Dundon T and Marchington M (2013) Employee Involvement and Voice in S. Bach and M. Edwards (eds), Managing Human Resources, 5th edition, Oxford: Blackwell, 2013, pp. 268-288

Wilkinson, A., Donaghey, J., Dundon, T. and Freeman, R. (2014). 'Employee voice: Charting new terrain’. In Wilkinson, A., Donaghey, J., Dundon, T. and Freeman, R. (eds), The Handbook of Research on Employee Voice. Cheltenham: Elgar Press, pp 3-16.

Wright Mills, C. (1948). The New Men of Power: America's Labor Leaders. New York: Harcourt Brace. 